\title{
The sexuality scripts constructed by nurses and an interface with attention of sexually transmited infection/HIV
}

\author{
Roteiros de sexualidade construídos por enfermeiros e a interface com a atenção em infecções \\ sexualmente transmissíveis/HIV \\ Guías de la sexualidad construidos por enfermeros y la interfaz con la atención en enfermedades \\ transmitidas sexualmente/HIV
}

\begin{abstract}
Sheila Milena Pessoa dos Santos ${ }^{1}(1)$ Javanna Lacerda Gomes da Silva Freitas ${ }^{2}$ (D) Maria Imaculada de Fátima Freitas ${ }^{1}$ (D)
\end{abstract}

1. Universidade Federal de Minas Gerais. Belo Horizonte, MG, Brasil.

2. Universidade Estadual da Paraíba. Campina Grande, PB, Brasil.
Corresponding author:

Sheila Milena Pessoa dos Santos.

E-mail: sheila.milena@gmail.com

Submitted on 03/16/2019.

Accepted on 05/24/2019.

DOI: 10.1590/2177-9465-EAN-2019-0078en

\begin{abstract}
Objective: To understand the routines of sexuality constructed by nurses and the interface with attention in STI/HIV in primary health care. Method: Qualitative study, anchored in the theory of sexual scripts. A total of 35 in-depth interviews were conducted with nurses from the Family Health Strategy between May and August 2017. The material was organized using MAXQDA Standard $12^{\circledR}$ software and was submitted to Structural Analysis of Narration and content. Results: The analysis of participants' trajectories allowed the construction of three categories: sexuality scripts in childhood and adolescence; scripts of sexuality in formation sexuality scripts and STI/HIV care. Conclusion and implications for practice: Sexuality scripts are marked by stereotypes, constructed throughout life, and result in obstacles to STI/HIV prevention practices. It was pointed out the need for investments in vocational training processes that focus on the paradigm shift in health and consider the cultural constructions that hinder the insertion of sexuality into care practices, with emphasis on preventive actions in STI/HIV.
\end{abstract}

Keywords: Sexuality; Sexually Transmitted Diseases; Human Immunodeficiency Virus; Nurses; Primary Health Care.

\section{Resumo}

Objetivo: Compreender os roteiros de sexualidade construídos por enfermeiros e a interface com a atenção em IST/HIV na atenção primária à saúde. Método: Estudo qualitativo, ancorado na teoria dos roteiros sexuais. Foram realizadas 35 entrevistas em profundidade com enfermeiros da Estratégia Saúde da Família, entre maio e a agosto de 2017. O material foi organizado com auxílio do software MAXQDA Standard $12^{\circledR}$ e foi submetido à Análise Estrutural de Narração. Resultados: A análise das trajetórias dos participantes permitiu a construção de três categorias: roteiros de sexualidade na infância e na adolescência; roteiros de sexualidade na formação; roteiros de sexualidade e o cuidado em IST/HIV. Conclusão e implicações para prática: Os roteiros de sexualidade são marcados por estereótipos e resultam em obstáculos às práticas de prevenção das IST/HIV. Apontou-se a necessidade de investimentos nos processos de formação profissional que focalizem a mudança de paradigma na saúde e considerem as construções culturais que dificultam a inserção da sexualidade nas práticas de cuidado, com destaque para as ações preventivas em IST/HIV.

Palavras-chave: Sexualidade; Infecções Sexualmente Transmissíveis; Vírus da Imunodeficiência Humana; Enfermeiras e Enfermeiros; Atenção Primária à Saúde.

\section{Resumen}

Objetivo: Comprender las guías de la sexualidad construidas por enfermeros y la interfaz con la atención en IST/HIV en la atención primaria de la salud. Método: Estudio cualitativo, anclado en la teoría de las guías sexuales. Se realizaron 35 entrevistas en profundidad con enfermeros de la Estrategia Salud de la Familia, entre mayo y agosto de 2017. El material se organizó con la ayuda del software MAXQDA Standard $12^{\circledR}$ y se sometió al Análisis Estructural de Narración y de contenido. Resultados: El análisis de las trayectorias de los participantes permitió la construcción de tres categorías: guías de sexualidad en la infancia y en la adolescencia; guías de la sexualidad en la formación; guías de la sexualidad y el cuidado en IST/VIH. Conclusión e implicaciones para la práctica: Las guías de la sexualidad están marcadas por estereotipos y resultan en obstáculos para las prácticas de prevención de las IST/VIH. Se apunta la necesidad de inversiones en los procesos de formación profesiona que se enfoquen en el cambio de paradigma en la salud y consideren las construcciones culturales que dificultan la inserción de la sexualidad en las prácticas de cuidado, con énfasis en las acciones preventivas en IST/VIH.

Palabras clave: Sexualidad; Infecciones de Transmisión Sexual; Virus de la Inmunodeficiencia Humana; Enfermeros; Atención Primaria de la Salud. 


\section{INTRODUCTION}

Sexuality is expressed from the interrelationship between biological, psychological, cultural, ethical and religious or spiritual aspects. ${ }^{1}$ It is a learning that consists of complex social scripts, introjected through life, under historical and cultural circumstances. $^{2}$ This perspective distances itself from the biomedical and essentialist notion of sexuality, associated with genitality, sexual intercourse and reproduction.

In health, interest in the topic of sexuality is largely due to the concern that unprotected sexual practices are associated with a huge global burden of disease. ${ }^{3}$ In this area, the dimension of sexuality plays a central role in preventive approaches in health, however this theme is still little punctuated in health care. ${ }^{4}$

The frailties of approaching sexuality in health care involve a variety of personal and contextual reasons. Professionals still regard sexuality as a sensitive and sensitive issue pertaining to the private sphere. ${ }^{5}$ In nursing, the theme has been associated with taboos and prejudices, present both in academic training and in professional practice. It is emphasized that in the interrelation of those who practice care and who receives it, sexuality gains space to emerge as a target for intervention. However, when veiled, sexuality may consist of anxieties, uncertainties, and constraints that have implications for care. ${ }^{6}$

The difficulties of professionals to approach sexuality produce consequences for effective nursing care, especially when it comes to improving the quality of life or preventing injuries. Low investment in this dimension can contribute to health problems such as Sexually Transmitted Infections (STIs) and Human Immunodeficiency Virus (HIV) infection remain as public health problems with negative impact on quality of life and interpersonal relationships. ${ }^{7}$

World Health Organization (WHO) reiterates that the change in the outlook for STI/HIV infection versus reduction is related to effective prevention practices. In this sense, preventive strategies include comprehensive sex education, acquisition of STI/HIV, body and gender, as well as advice on safe sex and behavioral changes, which require the construction and reconstruction of knowledge. These aspects refer to sexuality and should be the target of professional health practices. ${ }^{8}$

It should be emphasized that care in STI/HIV is crosscutting in care practices and should permeate all levels of health care because, because of the health consequences, sexually transmitted infections may require assistance in primary, secondary or tertiary services. ${ }^{9}$ However, in the scope of Primary Health Care (APS), the focus is on investment in prevention actions, mainly because of the effectiveness and positive impact of controlling the epidemic. ${ }^{3}$

As an integral part of the APS, it is emphasized that in the context of the Family Health Strategy (ESF), the nursing professional plays an essential role in STI/HIV care through individual consultation, group activities, request for exams, prescription of medication and referral, when necessary, of users to other services. ${ }^{9}$ However, studies report gaps in nursing practice for the prevention of STI/HIV and indicate the nurse's distancing from issues related to sexuality. ${ }^{5,6,10}$

Despite identifying gaps, health research has not invested in knowing the processes that lead nurses to avoid approaching sexuality in their practices. ${ }^{5,11,12}$ In this sense, this study focuses on the intersubjective, interpersonal and cultural contexts of the social interactions involved in the interpretations about sexuality and the implications for the care practices in STI/HIV. This knowledge is essential because it can identify aspects of nursing practice that contribute to the prevention actions being effective to control the epidemic.

Thus, nurses were questioned about lifelong sexuality, including learning about it and about STI/HIV. Therefore, the objective was to understand the routines of sexuality constructed by nurses and the interface with attention in STI/HIV in primary health care.

\section{METHOD}

It is part of a descriptive study, with a qualitative approach, anchored in the theory of sexual scripts. ${ }^{2}$ As cognitive projects, sexual scripts allow organizing and linking what people think and do and how they are affected by the sociocultural context in which they live.

Sexual routing involves three dimensions: cultural scenarios, which guide the requirements of social roles; interpersonal scripts, which correspond to the pattern of social interaction; and intrapsychic scripts, which consist of the person's internal dialogue with social and cultural expectations. Social actors trigger these scripts in everyday actions, which are the interpretation of social norms and cultural myths. ${ }^{13}$ In the present study, the theory of sexual scripts contributed to the understanding of how lifelong constructions on sexuality can guide practitioners' practices in STI/HIV care actions in the context of APS.

The research scenario was the APS field of a municipality in the northeast of Brazil, which has 105 ESF teams, organized in six health districts. The population was composed of nurses and nurses of these teams, being included: professionals in effective exercise and who had been working for more than a year in the team. This choice had the objective of guaranteeing the participant's connection to the service, allowing the narratives about the professional experiences. Professionals removed from the service by leave or leave were excluded.

The sample included professionals from all health districts and was conducted by lot. The information was preliminarily analyzed in the course of the collection, which allowed to confirm the theoretical saturation of the data ${ }^{14}$ and suspend the inclusion of new participants. Thus, the final sample totaled 35 professionals. 
Contact with the participants occurred by telephone and visits to the service. Only two nurses refused the participation, justified by personal reasons. After the consent of the participants, the data was collected, which took place between May and August 2017 , through in-depth interviews. ${ }^{15}$ The interviews were carried out in the nurses' offices, in their respective health units, according to the availability of the professional. Initially, identification data containing service time, sex and sexual orientation, age, number of children, existence of partnerships and data on academic training were collected. Participants were then asked to discuss lifelong experiences of sexuality, including learning about it and about STI/HIV. With the aim of offering confidence and providing free exposure of the narratives by the participants, the interviews were conducted with minimal interference and interpellations, except for the moments in which it was necessary to return to the central theme of the study or to deepen an idea. The interviews lasted 40 minutes on average, were audio recorded and transcribed integrally.

The analysis of the data was based on the structural analysis of narration, ${ }^{16}$ presupposing that the narrative occurs in a process of construction and reconstruction of proposed reflections in the interaction between researcher-interviewed, in which the second emits his representations about objects, giving meaning to what he thinks and speaks. It is added that in the structure of the narratives three articulated descriptive levels were observed: the level of the functions, in which the events, events or circumstances on the subject matter were described, identifying the sequences (S) and the facts (F); the level of actions, which consisted in the definition of the characters $(P)$, considered participants in a sphere of actions and in their praxis; the level of narration, in which the arguments and explanations used $(\mathrm{J})$ were identified on the facts described.

It was considered that the interpretation of a narrative does not only correspond to the accompaniment of a story, but consists in reconstructing the argumentative web of the interviewee, because the narrator does so in the comings and goings of the discourse. ${ }^{17}$ Thus, analysis was developed according to the following procedure ${ }^{18}$ : a) vertical reading to identify the central theme; b) horizontal reading to identify the sequences contained in the narratives, enumeration of facts, feelings, justifications and characters; regrouping of sequences by subject and provisional appointment of each regrouping; c) transversal reading to identify conjunctions and disjunctions of the facts narrated in the set of interviews; d) interpretation of the empirical categories, with the comparison of the categories found with studies on the theme.

To aid in the organization of the data, MAXQDA Standard $12^{\circledR}$ software was used. The software had only as function the organization of the characteristics of the participants and of the narrative cuts in the phases of vertical and horizontal reading of the analysis. All material was organized and interpreted by the authors, conferring the reliability and internal validity of the results.
The standards for human research contained in Resolution $466 / 12$ of the National Health Council were met and the study was approved by the research ethics committees of the Federal University of Minas Gerais on March 13, 2017 and the Hospital University Alcides Carneiro, on March 20, 2017, under opinions 1.961.797 and 1.973.639, respectively. In order to preserve the secrecy of the information and the anonymity of the participants, the segments of the narratives were identified using the letter $E$ (interviewed) and the random number assigned to each of the participants, between 1 and 35, followed by the letter F (female) or M (male).

\section{RESULTS}

\section{Characterization of participants}

Thirty-five nurses, female (86\%) and male (14\%), cisgenic, participated in the study. The age ranged from 25 to 55 years old, predominantly those older than 35 years old (68\%). Most have children (83\%), have sexual partners (86\%), have graduated from a public institution ( $77 \%$ ) for more than 10 years $(71 \%)$, have qualified as a specialist $(71 \%)$ and are for 10 years $(68 \%)$ in the ESF under statutory regime (86\%). Only two (5.7\%) professionals had continued training with the inclusion of themes related to sexuality and prevention of STI/HIV.

The results were synthesized in Figure 1 and represent cuts in the trajectories of the participants reconstituted over the life span from the following dimensions: cultural scenarios, interpersonal scripts and intrapsychic scripts.

The results were organized into three categories and are presented below.

\section{Scripts of sexuality in childhood and adolescence}

For the participants, the sexuality scripts were initially delineated within the context of the family, based on expectations and the modeling of behaviors according to biological sex.

Girl had to sit with her leg closed, cannot show her panties, wear short skirts, wear shorts, transparent blouse, or think $[\ldots](E 15, F)$.

I was taught that a boy does not mix with a girl. Girl is with girl play $(E 8, M)$.

The narratives showed the relationship with the parents and the peers, the learning about the body and the delimitation of the games. These experiences of socialization modeled the male and female performances against sexuality and unveiled gender scripts. In this understanding, a participant established a relationship between these devices and the sociocultural function.

Nowadays, I know that the girl's games already condition the woman to follow a certain role and the boy's play also $(E 15, F)$. 
Figure 1. Nurses' trajectories reconstituted from the dimensions: cultural scenarios, interpersonal and intrapsychic scripts. Source: Research data, 2017.

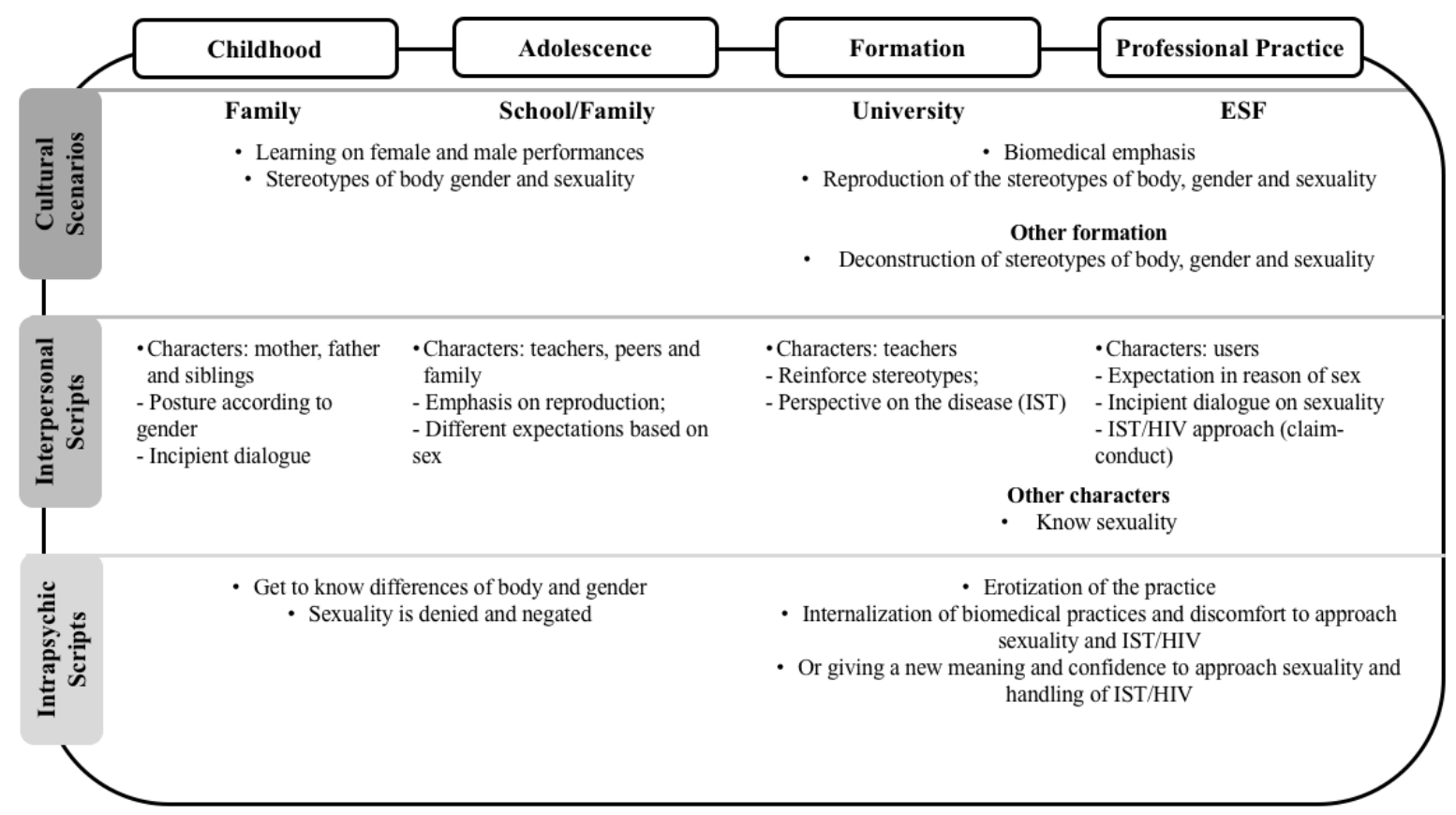

In adolescence the conservative stance of the parents was remarkable, there being no room for discussion and guidance on issues of sexuality, produced by scripts of silence and denial.

There was no such guidance to sit the son and talk eye to eye about it. Usually, they were very indirect advice. Alerting about not getting pregnant and getting STI (E12, M).

For some, the mother was the possible interlocutor, but following the norms of the father, with well-defined and expected gender roles:

Although my mother's greatest influence was on my mother, but in that respect, it was everything my father wanted. The one who enforced the rules for us was my mother, but it was according to his will [father] (E31, F).

Recalling experiences in adolescence, the participants narrated experiences in other settings and inserted other characters in the interpersonal context. New peers, colleagues, teachers and the school have emerged as space and opportunities for communication on sexuality, incurring in the discussion of themes such as body and reproduction, even if punctually.
[...] had a teacher who was very open, was a professor of chemistry. As he gave the class, he would open the door to talk about it and we would get questions about sexuality. Only it had a negative impact in the city. It came out in a newspaper. Just because in class it was asked what the clitoris is. The parents, when they saw it, I think it was the first year that happened, they did not like it and had a lot of negative repercussions in the school (E9, M).

Negative experiences about the discussion on subjects related to sexuality show that the insertion of the thematic, when it occurred, was permeated by conflicts and interdictions in the social field. Therefore, sexuality was treated as taboo and produced effects, such as the difficulty of approaching related themes. The debate in adolescence came, occasionally, around issues such as pregnancy, according to the interviewees.

The biology teacher is the one who made these explanations about body change, puberty, menstruation, about the [sexual] relationship that could become pregnant, but it was always about the biology discipline, it was not directed at anything (E25, F). 
Throughout the interviews, it was explained that information and dialogue about STI/HIV were fragmented, both in relation to parents and peers, and in school. Therefore, this subject was scarcely punctuated, although it was present in the participants' experiences.

My generation followed the illness and death of Cazuza, who withdrew. This was seen in the press and discussed at school in science classes. That was disease, it was a virus that attacked the immune system, which had no cure. They were terrifying campaigns in fact $(E 24, M)$.

The emergence of AIDS (1984) occurred at the time of adolescence and early adulthood for most participants. Appropriation over the disease has been permeated by stereotypes associated with people with HIV, homosexuality, signs in the body and death. The repercussion for the emergence of the virus was not accompanied by an enlightening discussion on issues of sexuality and STI/HIV.

The frailties of the sexuality and STI/HIV orientation have materialized in the low experience with prevention. Participants, both men and women, unveiled scripts in which unprotected sexual initiation and little knowledge about the subject were constant.

What they [friends, colleagues] were talking about was the act, what to do, what they had with the girl, they had this and that. No prevention, worrying about illness, or worrying about pregnancy $(E 8, M)$.

I thought [condom] was a swallowing thing [...]. My thought until college was that it was so (E5, F).

It emerges from the scripts examined that, regardless of gender, the lack of information regarding sexuality and the absence of insertion of STI/HIV protection and prevention issues predominated in the participants' contexts.

\section{Sexuality scripts during formation}

For the professionals, the entrance in the formation in nursing occurred in the beginning of the adult life and was the main scenario reported of the interactions in that phase. Part of them understood that this social context collaborated to experience new experiences but contributed little to break difficulties related to sexuality.

The university opened another world, for I came from the countryside. [...] but sexuality was not a subject matter in the content of the course $(E 24, M)$.

I think that's what changed my mind, the course. But for you to see what creation is, the course did not make me free from this shame that I have [with questions of sexuality] $(E 34, F)$.

The insertion of sexuality as a proposal contemplated during the classes in the graduation was mentioned by only three participants, in unique curricular components.

The teacher gave this part of STI, of cytology, but also aroused in us the history of sexuality, of people to respect, to know as woman, and made some dynamics on the body. I remember that it was there that I saw that sexuality went much further (E6, F).

The decision to include content on sexuality was exceptional at graduation and depended on the availability and attention of the teacher. Professionals justified that the greater emphasis on the course was directed at biological aspects and disease.

In my time, the teacher was more focused on discipline. This range was not open. There was no talk about sexuality. It was more content, biological, sick. There was not much talk about the behavior (E12, M).

The stereotypes of body and gender, present in the scripts of sexuality introjected throughout the life resurfaced in the formation. The taboo with the body and with the sexual physical manifestations were reported when referring to the practices in the stage fields.

I remember the first time I went for a catheter; it was a boy. I was very ashamed because the penis got hard. And I'm white, so I turned red. The teacher explained the technique and stated that the penis could stand erect, that this was something that over time we would break the taboo, the shame, and face it as a normal and uninvolved thing. But it was horrible (E32, F).

During the life forms and conduits were incorporated to hide, deny and silence the body and when faced with a situation of expression of sexuality, the lack of preparation was evident.

The participants also narrated different experiences based on the sex to which they belonged, while stereotypes remained.

Depending on some men who were indoors, when we went to bathe in bed, the teacher said that we sometimes had to take care of the issue of our own clothes, so as not to be tight or transparent, so as not to trigger any interest in man (E26, F).

Because I am a man [...], it was a very difficult task for me to do the cytological collection (E19, M). 
These reports reiterate that in the cultural scene of the academy, interpersonal and intrapsychic scripts introjected through life were reproduced, especially, directed to the interdictions of body and gender, extending, this time, to the care of the other.

As a prerogative of training, the STI approach emerged as a content taught in the discipline of women's health. However, the insertion of this content occurred mainly in a punctual and dissociated form of sexuality, with an emphasis on disease and treatment, according to the participants' reports.

We had to learn according to that catalog that has the STIs. He was talking about female and male condoms and treatment, but basically that was all $(E 28, F)$.

I remember that it was very superficial, but in a way directed to the pregnant woman, it was not that we're going to talk about STI, not (E21, F).

The superficiality narrated by the participants reveals that the teaching of STIs has been disconnected from learning about issues involving sexuality.

As an exception, some professionals participated in other training courses in insertion of the sexuality approach.

For those who did the course it was great. The question was raised that sexuality is not only about sex, that touching the hand, a smell is also sexuality [...] I think that we discussed the subject a lot and when people paid for women's health, , when we paid for the health of the man, we saw sexuality, when we saw the health of the elderly, we saw sexuality in the elderly (E5, F).

The demystification of sexuality, through these formations, was associated with the care practices marked by the openness to approach the theme, directed to a variety of audiences, such as the man, the elderly and the adolescent. This aspect has shown to be a contributor to the seizure of information and insertion of STI/HIV prevention actions, as will be shown below.

\section{Sexuality scripts and STI/HIV care}

In reporting their experiences in the professional practice, the participants insisted on the low insertion of sexuality issues in practices in the health services, being mentioned only during the visits to the health of women. This insertion was mentioned by the nurses, who reported occasionally approaching subjects related to sexuality with the users, although they reported discomfort in certain situations.

Seldom do I ask anything about it, about sexuality (E19, M).
People have arrived saying she was raped, had a lesbian relationship and now she was with a man. Sometimes you get kind of shocked by the things you hear and have to breathe to see what you're going to do (E3, F).

The (in) willingness of nurses to discuss sexuality with women illustrates gender routing, seized from the heterosexual perspective. In this sense, the unpreparedness and the absence of discussions that involved sexual and gender diversity were unveiled, as an example of the "shock" in the face of the demand for health care.

In the professional exercise, the participants also reported discomfort in the care of the body, especially of the opposite sex, which is also an expression of sexuality scripts learned during the life.

It's always a little embarrassing to deal with that part. It is never very comfortable (E2, $F$ ).

Difficulties in touching the body to care for users of the opposite sex were then especially reported by male professionals.

Women are not prepared to do exams in the gynecological area with male professionals $(E 12, M)$.

Since health care in FHT focuses on preventive actions in the sexual and reproductive spheres of women, with men practically absent, the difficulties to approach the male public were not punctuated by the nurses.

In this logic, STI/HIV care practices were concentrated in women of adulthood and sought the service to perform preventive activities related to sexual and reproductive health.

Syphilis in [male] adults, I had no case. I had syphilis in a pregnant woman. We found out in the first quarter through VDRL. It is when something appears (E27, F).

When the patient comes with a visible complaint [of STI] or when she already has a history of a promiscuous sex life, we provide care (E21, F).

Within a biological approach, the care provided to the female public occurs through risk behavior and is centered on the complaint-conduct dimension, with emphasis on the procedures to offer examinations and treatment of the identified alterations. Thus, in view of the need for intervention directed at the sexual partnership of women, care for the male user is performed indirectly and occurs during the treatment of the couple.

Since most of them do not come because they work, we make the prescription, and the woman even takes the medication from the pharmacy and takes it to her (E3O, F). 
STIs [in men] we usually treat when treating their partner [medication delivery] (E33, F).

Men do not talk. Few talk about any disease other than rheumatism, whether you smoke or drink. I think I did not treat and did not refer any male patients, related to STDs, because they are not open (E35, F).

Essentially, for participants the approach to STI/HIV only occurs from the user's search, through signs and symptoms.

Incredibly, we address [STI/HIV] only when the patient reports a complaint (E17, F).

In their approach, practitioners revealed that they felt uncomfortable communicating sexual aspects of STI/HIV. These attitudes were justified by the lack of express demand on the part of the clientele or by their lack of preparation, but also by a moral evaluation of the sexuality of the other.

I think I would be embarrassed if, for example, the woman had had 15 partners. Although they talk a lot, I think I would be ashamed to say that I had a relationship with 15 men (E20, F).

I have some difficulty. I have already had cases of the woman having some symptom and say: "my husband wanted to come and show." I sort of ducked and went to the doctor (E31, F).

These situations give visibility to the presence of scripts with stereotypes of sexuality which lead to ruptures in nursing care and in the prevention of STI/HIV.

Apart from the group, there were few reports on the approach to sexuality inserted in the service proposal, regardless of the user's gender, including attention to the man.

Men look for me and the doctor, whoever is available at the moment. We ask how you are relating, if you are with someone, because he may have a relationship with a man or a woman (E11, F).

We ask for HIV and VDRL for all hypertensive and diabetic patients. We already start offering them saying it's their right $(E 5, F)$.

Although from the biomedical perspective of the attention, including the greater emphasis on examinations, it is noteworthy that only those professionals who have had other formations that include the interface between sexuality and care have been shown to include more comprehensive actions for the prevention of STI/HIV.

\section{DISCUSSION}

There were no expressive differences in the scripts because of the generational aspects, parental or affective relationship, graduation and professional activity. It was understood that the complexity of the scripts and the conditions for operating them are of a psychological, social and cultural order, of which these variables are only a part.

The results showed that the participants were exposed to cultural scenarios, in which stereotypes about sexuality prevailed. These scripts support the senses and enable the organization of interpretations and practical dispositions learned throughout life. ${ }^{2}$ In the present research, these scripts also contributed to pushing issues about sexuality and sexual health from work in the daily life of APS services.

In considering the cultural and interpersonal contexts, it was explained that the socialization in childhood was centered on parental expectations, norms about the body and ways of playing, conformed differently for girls and boys. This learning was carried out through the construction of expected performances due to biological sex, revealing gender nuances. The separation of the jokes in masculine and feminine, for example, carries strong prejudice. Thus, the symbolic norm, essentially oriented towards the distinction between the sexes, structures the hegemonic feminine and masculine identities, which later determine the performances and representations of sexuality..$^{19}$ It is reiterated that, after childhood, the importance of these experiences is more evident and they become more powerful in the sense of limiting and modeling individual behaviors. ${ }^{2}$

As a teenager, the dialogue on sexuality was always elementary in family and school, and dependent on the willingness of one or another teacher to address them. When the theme emerged, it focused on passing fragmented information on reproduction and on STI/HIV, usually around prohibitions or warnings, with no room for dialogue about the affective and sexual experiences necessary for prevention. In these aspects, a study revealed that the difficulty of approaching these issues with adolescents is still a current problem and may have an impact on the greater vulnerability to STI/HIV infection. ${ }^{20}$

In the professionalization, the low investment in aspects of sexuality in care was evidenced. This gap is identified in nursing, but also in a large part of health education curricula. ${ }^{21}$ However, the silence about sexuality in the training does not imply the absence of these questions, for it was identified, for example, the differentiation of care based on sex, revealing the eroticization of the care relationship. This result was found in another study carried out with French nurses. ${ }^{22}$ The authors concluded that the eroticization present in the context of care can cause impediments in the relations between professional and user. In the present study, it was shown that barriers to the body may be impeding care, since difficulties to perform the physical examination, for example, may hamper access and identification of signs and symptoms of STI/HIV in users in the APS. 
In the professional trajectories, it was evidenced that the emphasis was the hegemonic biomedical model, which was related to fragmented actions in STI/HIV care. These actions are based on the complaint-conduct and the offer of examinations, through behaviors considered at risk and in the presence of signs and symptoms of infection. This perspective is reinforced against the proposal for prevention of STI/HIV, focusing on the vulnerability perspective. The importance of this concept lies in the interpretation and identification of factors that increase the probability of infection in certain population segments, including the identification of asymptomatic infections in vulnerable populations. ${ }^{23}$ This is possible through vulnerability identification, detailed sexual history and offer of prevention interventions, such as condoms, vaccines and tests. ${ }^{24}$

However, it has been shown that professionals do not invest much in the approach of men and women, even in the context of sexual and gender diversity. It was considered that this gap could represent barriers to the population's access to STI/HIV care. In this regard, a study of older people has shown that there is a loss of opportunities in the identification and treatment of $\mathrm{STI} / \mathrm{HIV}$ in health services because professionals are reluctant to address sexuality issues with this public. ${ }^{25}$ Another study carried out in Argentina revealed the low perception of women who have sex with women on STIs. According to the authors, the incipient access to information on the subject increases while these women silence their sexual practices because of the lack of dialogue and the assumption of the health professional that they are heterosexual. ${ }^{26}$ Similar results have been found in studies that prevention of STI/HIV in men. ${ }^{27,28}$ Predominantly, these studies denounce male vulnerability due to stigma and discrimination, also present in health services.

The development of prevention actions in STI/HIV has proved difficult in a context in which nurses do not discuss sexuality. Accordingly, the Pan American Health Organization (PAHO) reinforces that barriers to discussion on sexual health and sexuality hinder communication for prevention of STI/HIV in primary care services and accentuate the barriers faced by users to access interventions. ${ }^{3}$

Contrary to the orientation to approach free of prejudices about sexual practices with users and their partnerships, the narratives revealed the discomfort of professionals with the subject. A similar result was found in another study, which identified the professionals' unpreparedness to approach sexuality with users. The authors considered that the professionals, with no resources to address the issue, opted to omit and avoid the demands of sexuality brought by the user and, in this way, contributed to increase the vulnerability of users to STI/HIV. ${ }^{4}$

It should be emphasized that the process of socialization is also marked by the creation, reorganization and destruction of parts of the script, by means of responses to new skills and concrete situations. ${ }^{2}$ In the analyzed context, there was little evidence of these new skills, which would be possible through institutional support and training processes that encourage dialogue about sexuality and the acquisition of knowledge on the subject. ${ }^{29}$ In part, this investment occurred only for some professionals who have shown a better understanding, with some repercussion in the approach to the users of STI/HIV care in primary care.

\section{CONCLUSION AND IMPLICATIONS FOR PRACTICE}

The reconstruction of nurses' trajectories revealed that learning about sexuality occurred via stereotypes. In the contexts experienced, the social interactions assumed relevance, without being discussed, but affective and sexual issues necessary for the practices of prevention of STI/HIV. Particularly, in the professional setting, there was clearly a strong biomedical orientation, and no socio-cultural approach to sexuality was identified. Thus, STI/HIV care has been viewed from the perspective of the manifest illness, without consideration of the vulnerability processes of APS users.

It can be concluded that there are socially constructed sexuality scripts, which define attitudes and postures that are unfavorable to the insertion of the subject as an object of care, reflecting barriers to preventive practices in STI/HIV. It is emphasized that those professionals who have had cultural learning who cooperated to break with myths and taboos of sexuality have, at least in part, revealed a differentiated disposition and insertion of the approach on sexual practices and STI/HIV with users in services.

The results of the study show the need for interventions in the processes of formation that focus on intersubjective, interpersonal and cultural contexts that hinder the insertion of sexuality into care practices. Such an investment can help nurses understand how their knowledge can contribute to improving STI/ HIV prevention actions in APS.

\section{Funding}

PhD grant awarded by the Coordination for the Improvement of Higher Education Personnel (CAPES, No. 023/2014).

\section{REFERENCES}

1. Juárez G, Ramírez PG. Significado de los derechos sexuales em estudiantes de licenciatura em Enfermería. Rev Iberoam Educ Invest Enferm [Internet]. 2016 oct/dec; [cited 2019 jan 10]; 6(4):9-17. Available from: https://www.enfermeria21.com/revistas/aladefe/articulo/217/ significado-de-los-derechos-sexuales-en-estudiantes-de-licenciaturaen-enfermeria/

2. Gagnon JH. Uma interpretação do desejo: ensaios sobre o estudo da sexualidade. Rio de Janeiro (RJ): Garamond; 2006. 
3. Organização Mundial de la Salud (OMS). Organización Panamericana de la Salud (OPAS). Comunicaciones breves relacionadas com la sexualid. Recomendaciones para um enfoque de salud pública [Internet]. Washington, D.C.: Organización Panamericana de la Salud - OPAS; 2018; [cited 2019 feb 21]. Available from: http://iris.paho.org/ xmlui/bitstream/handle/123456789/49504/9789275320174_spa. pdf?ua $=1$

4. Barbosa JAG, Souza MCMR, Freitas MIF. A abordagem da sexualidade como aspecto essencial da atenção integral de pessoas com transtornos mentais. Ciên Saúde Colet [Internet]. 2015 jul; [cited 2019 feb 2]; 20(7):2165-2172. Available from: https://doi.org/10.1590/141381232015207.01792014

5. Ferreira SMA, Gozzo TO, Panobianco MS, Santos MA, Almeida AM Barriers for the inclusion of sexuality in nursing care for women with gynecological and breast cancer: perspective of professionals. Rev Latino-Am Enferm [Internet]. 2015 feb; [cited 2018 feb 10]; 23(1):82-89. Available from: https://doi.org/10.1590/0104-1169.3602.2528

6. Sehnem GD, Ressel LB, Junges CF, Silva FM, Barreto CN. A sexualidade na formação acadêmica do enfermeiro. Esc Anna Nery [Internet]. 2013 mar; [cited 2019 feb 21]; 17(1):90-96. Available from: http://dx.doi. org/10.1590/S1414-81452013000100013

7. Organización Mundial de la Salud (OMS). Estrategia mundial del sector de la salud contra las infecciones de transmisión sexual 2016-2021 [Internet]. Geneva: World Health Organization; 2016 jun; [cited 2019 feb 21]. Available from: http://apps.who.int/iris/bitstream/10665/250253/1/ WHO-RHR-16.09-spa.pdf?ua $=1$

8. World Health Organization (WHO). Sexually transmitted infections (STIs). Fact sheet Updated [Internet]. Geneva: World Health Organization; 2016 aug; [cited 2019 feb 21]. Available from: https://www.who.int/ news-room/fact-sheets/detail/sexually-transmitted-infections-(stis)

9. Ministério da Saúde (BR). Secretaria de Vigilância em Saúde. Departamento de DST, Aids e Hepatites Virais. Protocolo Clínico e Diretrizes Terapêuticas (PCDT). Atenção Integral às Pessoas com Infecções Sexualmente Transmissíveis (IST). 2a ed. Brasília (DF): Ministério da Saúde; 2015; [cited 2019 feb 21]. Available from: http:// bvsms.saude.gov.br/bvs/publicacoes/protocolo_clinico_diretrizes_ terapeutica_atencao_integral_pessoas_infeccoes_sexualmente_ transmissiveis.pdf

10. Belém JM, Alves MJH, Pereira EV, Maia ER, Quirino GS, Albuquerque GA. Prostituição e saúde: representações sociais de enfermeiros/as da Estratégia Saúde da Família. Rev Baiana Enferm [Internet]. 2018; [cited 2019 feb 2]; 32:e25086. Available from: http://dx.doi.org/10.18471/rbe. v32.25086

11. Albuquerque GA, Leite MF, Belém JM, Nunes JFC, Oliveira MA, Adami F. O homem na atenção básica: percepções de enfermeiros sobre as implicações do gênero na saúde. Esc Anna Nery [Internet]. 2014 out/ dez; [cited 2019 jan 30]; 18(4):607-614. Available from: http://dx.doi. org/10.5935/1414-8145.20140086

12. Bungay V, Masaro CL, Gilbert M. Examining the scope of public health nursing practice in sexually transmitted infection prevention and management: what do nurses do?. J Clin Nurs [Internet]. 2014 mar; [cited 2019 feb 2]; 23(21-22):3274-3285. Available from: http://dx.doi. org/10.1111/jocn. 12578

13. Gagnon JH, Silva LR, Carrara S, Sívori H. Uma interpretação do desejo: ensaios sobre o estudo da sexualidade. Tradução de Lucia Ribeiro da Silva. Rio de Janeiro (RJ): Garamond Universitária; 2006.

14. Fontanella BJB, Ricas J, Turato ER. Amostragem por saturação em pesquisas qualitativas em saúde: contribuições teóricas. Cad Saude Publica [Internet]. 2008 jan; [cited 2018 feb 21]; 24(1):17-27. Available from: http://dx.doi.org/10.1590/S0102-311X2008000100003
15. Flick W. Introdução à pesquisa qualitativa. 3a ed. Porto Alegre: Artmed; 2009.

16. Demaziere D, Dubar C. Analyser les entretiens biographiques: L'exemple de récits d'insertion. Paris: Nathan, Coll. Essais \& Recherches; 1997.

17. Barthes $R$, et al. Introdução à Análise Estrutural da Narrativa. In: Barthes $\mathrm{R}$, et al. Análise Estrutural da Narrativa. 8a ed. Petrópolis (RJ): Vozes; 2013.

18. Blanchet A, Gotman A. L'enquête et ses méthodes: l'entretien. Paris: Nathan; 1992.

19. Costa LHR, Coelho EAC. Ideologies of gender and sexuality: the interface between family upbringing and nursing education. Texto Contexto - Enferm [Internet]. 2013 jun; [cited 2018 feb 19];22(2):485-492. Available from: http://dx.doi.org/10.1590/S0104-07072013000200026

20. Almeida RAAS, Corrêa RGCF, Rolim ILTP, Hora JM, Linard AG Coutinho NPS, et al. Knowledge of adolescents regarding sexually transmitted infections and pregnancy. Rev Bras Enferm [Internet]. 2017 oct; [cited 2019 may 01]; 70(5):1033-1039. Available from http://www.revenf.bvs.br/scielo.php?script=sci_arttext\&pid=S003471672017000501033\&Ing=pthttp://dx.doi.org/10.1590/0034-71672016-0531

21. Mann CG, Monteiro S. Sexualidade e prevenção das IST/aids no cuidado em saúde mental: o olhar e a prática de profissionais no Município do Rio de Janeiro, Brasil. Cad Saude Publica [Internet]. 2018; [cited 2019 may 06]; 34(7):e00081217. Available from: http://dx.doi.org/10.1590/0102$311 \times 00081217$

22. Giami A, Moulin P, Moreau E. La place de la sexualité dans le travail infirmier: l'érotisation de la relation de soins. Sociol Trav [Internet]. 2013 jan/mar; [cited 2019 feb 22]; 55(1):20-38. Available from: https://doi. org/10.1016/j.soctra.2012.12.001

23. Ministério da Saúde (BR). Secretaria de Vigilância em Saúde. Departamento de Vigilâcia, Prevenção e Controle das Infecções sexualmente. Prevenção e Controle das Infecções Sexualmente Transmissíveis, do HIV/Aids e das Hepatites Virais. Prevenção Combinada do HIV/Bases conceituais para profissionais, trabalhadores(as) e gestores(as) de saúde. Brasília: Ministério da Saúde; 2017.

24. Wilkin T. Primary care for men who have sex with men. N Engl J Med [Internet]. 2015 aug; [cited 2019 may 05]; 373:854-862. Available from: https://www.nejm.org/doi/10.1056/NEJMcp1401303

25. Andrade J, Ayres JA, Alencar RA, Duarte MTS, Parada CMGL. Vulnerabilidade de idosos a infecções sexualmente transmissíveis. Acta Paul Enferm [Internet]. 2017 jan; [cited 2019 may 03]; 30(1):8-15. Available from: http://dx.doi.org/10.1590/1982-0194201700003

26. Silberman P, Buedo PE, Burgos LM. Barreras en la atención de la salud sexual en Argentina: percepción de las mujeres que tienen sexo con mujeres. Rev Salud Pública [Internet]. 2016 jan; [cited 2019 may 01] 18(1):1-12. Available from: http://dx.doi.org/10.15446/rsap.v18n1.48047

27. Baker P, Dworkin S, Tong S, Banks I, Shand T, Yamey G. The men's health gap: men must be included in the global health equity agenda. In World Health Organization (WHO). Bull World Health Organ [Internet]. 2014; [cited 2019 may 05]; 92:618-620. Available from: http://dx.doi. org/10.2471/BLT.13.132795

28. Reidy DE, Brookmeyer KA, Gentile B, Berke DS, Zeichner A. Gender role discrepancy stress, high-risk sexual behavior, and sexually transmitted disease. Arch Sex Behav [Internet]. 2016 feb; [cited 2019 may 05] 45(2):459-465. Available from: http://dx.doi.org/10.1007/s10508-0140413-0

29. Saunamäki N, Engström MJ. Registered nurses' reflections on discussing sexuality with patients: responsibilities, doubts and fears. J Clin Nurs [Internet]. 2014 oct; [cited 2019 may 05]; 23(3-4):531-540. Available from: http://dx.doi.org/doi:10.1111/jocn.12155 